GSA Data Repository Items for "Mountain erosion over 10-year, 10 000-year, and 10000 000-year time scales", by James W. Kirchner, Robert C. Finkel, Clifford S. Riebe, Darryl E. Granger, James L. Clayton, John G. King, and Walter F. Megahan

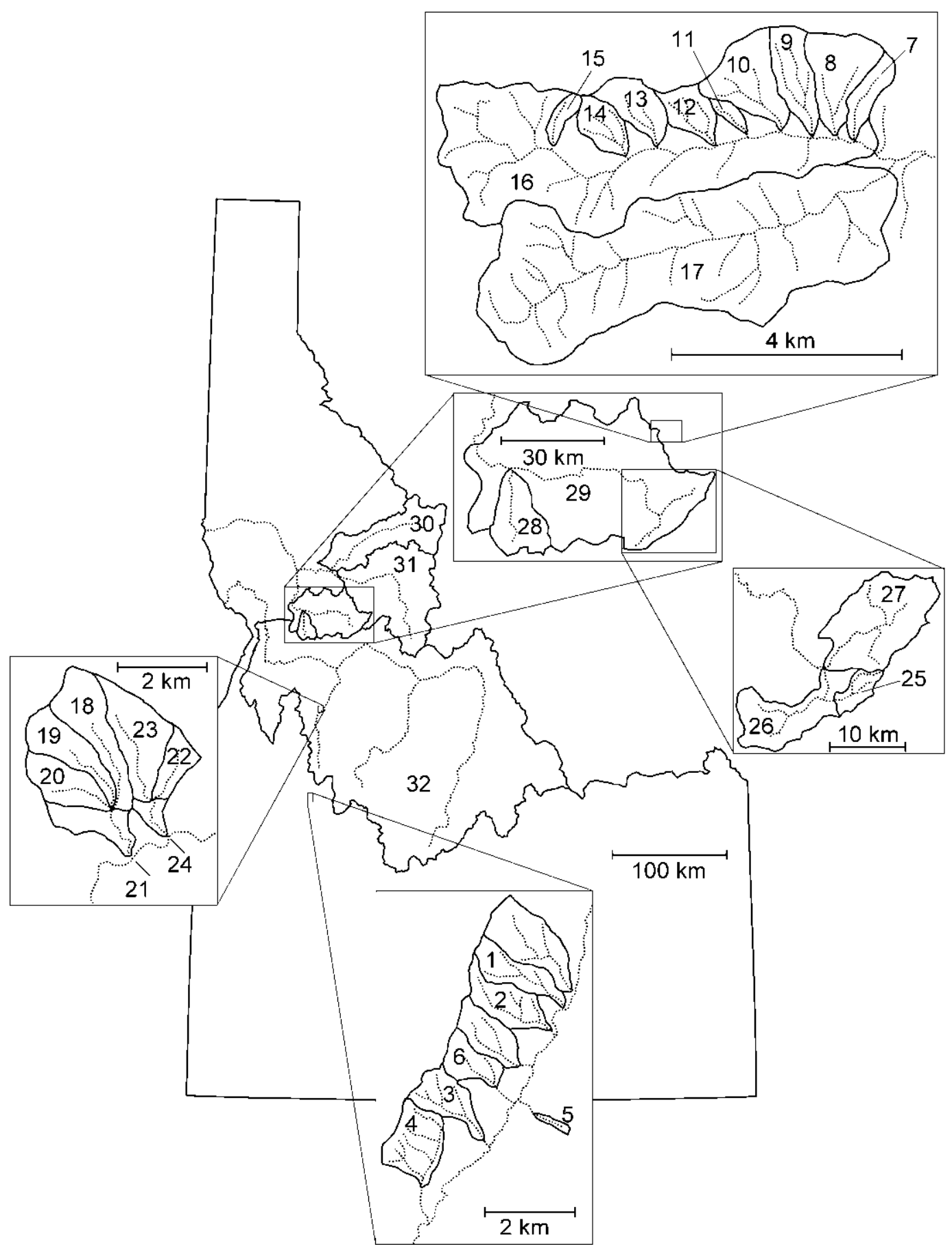

Figure A. Study catchment boundaries (solid lines) and major streams (dotted lines), superimposed on outline map of the state of Idaho. Catchment identification numbers are keyed to Table A. 
TABLE A. CATCHMENT CHARACTERISTICS AND SEDIMENT YIELDS

\begin{tabular}{|c|c|c|c|c|c|c|c|c|c|c|c|}
\hline \multirow{2}{*}{\multicolumn{2}{|c|}{$\begin{array}{l}\text { Catchment } \\
\text { ID* Name }\end{array}$}} & \multirow[b]{2}{*}{ Latitude } & \multirow[b]{2}{*}{ Longitude } & \multirow[b]{2}{*}{$\begin{array}{c}\text { Drainage } \\
\text { area } \\
\left(\mathrm{km}^{2}\right)\end{array}$} & \multirow[b]{2}{*}{$\begin{array}{c}\text { Altitude } \\
\text { range } \\
(\mathrm{m})\end{array}$} & \multirow[b]{2}{*}{$\begin{array}{l}\text { Glaciated } \\
\text { area } \\
(\%)\end{array}$} & \multicolumn{2}{|c|}{ Short-term rates } & \multicolumn{3}{|c|}{ Long-term (cosmogenic) rates } \\
\hline & & & & & & & $\begin{array}{l}\text { Record } \\
\text { length } \\
(y r)\end{array}$ & $\begin{array}{c}\text { Sediment } \\
\text { yield }^{\dagger} \\
\left(\mathrm{T} \cdot \mathrm{km}^{-2} \cdot \mathrm{yr}^{-1}\right)\end{array}$ & $\begin{array}{c}{ }^{10} \mathrm{Be} \\
\text { concentration }{ }^{\S} \\
\left(10^{5} \text { atom } \bullet \mathrm{g}^{-1}\right)\end{array}$ & $\begin{array}{c}\text { Time } \\
\text { scale } \\
\text { (yr) }\end{array}$ & $\begin{array}{c}\text { Sediment } \\
\text { yield } \\
\left(\mathrm{T} \cdot \mathrm{km}^{-2} \cdot \mathrm{yr}^{-1}\right)\end{array}$ \\
\hline \multicolumn{12}{|c|}{ Silver Creek } \\
\hline 1 & SC-2 & $44^{\circ} 22 ' 20 "$ & $115^{\circ} 45^{\prime} 59^{\prime \prime}$ & 1.2 & $1463-2073$ & 0 & 27 & $13.2 \pm 2.2$ & $0.92 \pm 0.04$ & 5100 & $327 \pm 42$ \\
\hline 2 & SC-3 & $44^{\circ} 222^{\prime} 06^{\prime \prime}$ & $115^{\circ} 46^{\prime} 12^{\prime \prime}$ & 1.3 & $1451-2066$ & 0 & 28 & $8.9 \pm 1.4$ & $1.61 \pm 0.06$ & 9400 & $174 \pm 23$ \\
\hline 3 & SC-5 & $44^{\circ} 20^{\prime} 46^{\prime \prime}$ & $115^{\circ} 47^{\prime} 18^{\prime \prime}$ & 1.1 & $1390-1772$ & 0 & 28 & $10.9 \pm 1.6$ & $1.87 \pm 0.07$ & 12000 & $136 \pm 18$ \\
\hline 4 & SC-6 & $44^{\circ} 20^{\prime} 15^{\prime \prime}$ & $115^{\circ} 48^{\prime} 20^{\prime \prime}$ & 1.6 & $1381-1784$ & 0 & 27 & $9.3 \pm 1.7$ & $1.72 \pm 0.11$ & 11000 & $152 \pm 22$ \\
\hline 5 & SC-7 & $44^{\circ} 21^{\prime} 01 "$ & $115^{\circ} 46^{\prime} 30^{\prime \prime}$ & 0.23 & $1457-1819$ & 0 & 22 & $14.4 \pm 2.5$ & $2.88 \pm 0.11$ & 17000 & $90 \pm 12$ \\
\hline 6 & SC-8 & $44^{\circ}-21 ' 21 "$ & $115^{\circ} 47^{\prime} 02^{\prime \prime}$ & 1.1 & $1415-1720$ & 0 & 13 & $30.0 \pm 10.6$ & $2.06 \pm 0.09$ & 13000 & $121 \pm 16$ \\
\hline \multicolumn{12}{|c|}{ Horse Creek } \\
\hline 7 & $\mathrm{HC}-2$ & 455'ㄱ' & 115²0'27" & 0.57 & $1268-1744$ & 0 & 10 & $7.3 \pm 1.3$ & $2.46 \pm 0.09$ & 16000 & $97 \pm 13$ \\
\hline 8 & $\mathrm{HC}-4$ & $45^{\circ} 59^{\prime} 44^{\prime \prime}$ & 11520'39" & 1.4 & $1280-1747$ & 0 & 10 & $3.5 \pm 0.6$ & $2.71 \pm 0.11$ & 18000 & $89 \pm 12$ \\
\hline 9 & HC-6 & $45^{\circ} 59^{\prime} 37^{\prime \prime}$ & $115^{\circ} 21^{\prime} 00^{\prime \prime}$ & 1.0 & $1293-1726$ & 0 & 15 & $3.3 \pm 0.6$ & $2.94 \pm 0.11$ & 19000 & $80 \pm 11$ \\
\hline 10 & $\mathrm{HC}-8$ & $45^{\circ} 59^{\prime} 41^{\prime \prime}$ & $115^{\circ} 21^{\prime} 26^{\prime \prime}$ & 1.5 & $1317-1726$ & 0 & 12 & $11.0 \pm 3.0$ & $2.64 \pm 0.13$ & 17000 & $90 \pm 13$ \\
\hline 11 & $\mathrm{HC}-9$ & $45^{\circ} 59^{\prime} 37^{\prime \prime}$ & 11521'53" & 0.23 & $1341-1646$ & 0 & 10 & $8.6 \pm 1.3$ & $2.86 \pm 0.09$ & 19000 & $80 \pm 11$ \\
\hline 12 & $\mathrm{HC}-10$ & $45^{\circ} 59^{\prime} 32^{\prime \prime}$ & 115-22'19" & 0.65 & $1354-1729$ & 0 & 12 & $9.9 \pm 2.4$ & $2.58 \pm 0.09$ & 17000 & $92 \pm 13$ \\
\hline 13 & $\mathrm{HC}-12$ & $45^{\circ} 59^{\prime} 30^{\prime \prime}$ & 115²3'07" & 0.83 & $1390-1804$ & 0 & 14 & $8.2 \pm 2.3$ & $2.48 \pm 0.08$ & 16000 & $101 \pm 14$ \\
\hline 14 & $\mathrm{HC}-14$ & $45^{\circ} 59$ '24" & 115-23'30" & 0.62 & $1415-1804$ & 0 & 12 & $7.5 \pm 2.3$ & $3.09 \pm 0.15$ & 19000 & $80 \pm 12$ \\
\hline 15 & $\mathrm{HC}-16$ & $45^{\circ} 59^{\prime} 27^{\prime \prime}$ & 115²4'31" & 0.21 & $1524-1768$ & 0 & 13 & $25.1 \pm 6.7$ & $4.36 \pm 0.15$ & 27000 & $55 \pm 8$ \\
\hline 16 & West Fork & $45^{\circ} 59^{\prime} 30^{\prime \prime}$ & 115²0'10" & 17 & $1250-1804$ & 0 & 23 & $5.0 \pm 0.5$ & $2.72 \pm 0.07$ & 18000 & $87 \pm 12$ \\
\hline 17 & East Fork & $45^{\circ} 59^{\prime} 20^{\prime \prime}$ & $115^{\circ} 19^{\prime} 58^{\prime \prime}$ & 14 & $1241-1835$ & 0 & 23 & $2.5 \pm 0.3$ & $3.12 \pm 0.09$ & 20000 & $76 \pm 11$ \\
\hline \multicolumn{12}{|c|}{ Tailholt \& Circle End Creeks } \\
\hline 18 & Tailholt $A$ & $45^{\circ} 03^{\prime} 11^{\prime \prime}$ & $115^{\circ} 40^{\prime} 54^{\prime \prime}$ & 2.2 & $1256-2369$ & 0 & 21 & $11.0 \pm 2.5$ & $1.18 \pm 0.07$ & 6300 & $264 \pm 36$ \\
\hline 19 & Tailholt B & 450' $10^{\prime \prime}$ & $115^{\circ} 40^{\prime} 57^{\prime \prime}$ & 1.6 & $1256-2141$ & 0 & 22 & $14.6 \pm 3.3$ & $1.15 \pm 0.05$ & 6400 & $262 \pm 34$ \\
\hline 20 & Tailholt C & $45^{\circ} 03^{\prime} 09^{\prime \prime}$ & $115^{\circ} 41^{\prime} 00^{\prime \prime}$ & 1.4 & $1256-2073$ & 0 & 22 & $13.7 \pm 2.4$ & $1.41 \pm 0.05$ & 8200 & $202 \pm 26$ \\
\hline 21 & Tailholt Main & 450'34" & $115^{\circ} 40^{\prime} 38^{\prime \prime}$ & 6.6 & $1091-2369$ & 0 & 28 & $14.0 \pm 2.8$ & $1.22 \pm 0.06$ & 7000 & $239 \pm 32$ \\
\hline 22 & Circle End A & $45^{\circ} 03^{\prime} 17^{\prime \prime}$ & $115^{\circ} 40^{\prime} 13^{\prime \prime}$ & 0.8 & $1296-2015$ & 0 & N.D. & N.D. & $1.23 \pm 0.05$ & 7300 & $226 \pm 29$ \\
\hline 23 & Circle End B & $45^{\circ} 03^{\prime} 16^{\prime \prime}$ & $115^{\circ} 40^{\prime} 17^{\prime \prime}$ & 2.3 & $1296-2369$ & 0 & N.D. & N.D. & $1.26 \pm 0.05$ & 7300 & $229 \pm 30$ \\
\hline 24 & Circle End Main & $45^{\circ} 02^{\prime} 50^{\prime \prime}$ & $115^{\circ} 40^{\prime} 01^{\prime \prime}$ & 3.8 & $1083-2369$ & 0 & 25 & $6.5 \pm 1.1$ & $1.30 \pm 0.07$ & 7700 & $215 \pm 29$ \\
\hline \multicolumn{12}{|c|}{ Larger Streams and Rivers } \\
\hline 25 & Trapper Creek & $45^{\circ} 40^{\prime} 13^{\prime \prime}$ & $115^{\circ} 19^{\prime} 47^{\prime \prime}$ & 20 & $1476-2012$ & 0 & 10 & $9.8 \pm 1.6$ & $4.67 \pm 0.12$ & 26000 & $57 \pm 8$ \\
\hline 26 & South Fk. Red River & $45^{\circ} 42^{\prime} 35^{\prime \prime}$ & 115-20'37" & 98 & $1320-2170$ & 0 & 14 & $8.0 \pm 1.4$ & $4.65 \pm 0.13$ & 25000 & $58 \pm 8$ \\
\hline 27 & Upper Red River & $45^{\circ} 42^{\prime} 38^{\prime \prime}$ & $115^{\circ} 20^{\prime} 34^{\prime \prime}$ & 129 & $1320-2075$ & 0 & 14 & $10.1 \pm 1.6$ & $3.03 \pm 0.10$ & 18000 & $87 \pm 12$ \\
\hline 28 & Johns Creek & $45^{\circ} 49^{\prime} 23^{\prime \prime}$ & $115^{\circ} 53^{\prime} 18^{\prime \prime}$ & 293 & $735-2551$ & 32 & 10 & $7.6 \pm 1.3$ & $2.60 \pm 0.09$ & 15000 & $108 \pm 15$ \\
\hline 29 & S. Fk. Clearwater Rvr & $45^{\circ} 53^{\prime} 15^{\prime \prime}$ & $116^{\circ} 01^{\prime} 47^{\prime \prime}$ & 2149 & $600-2551$ & 7 & 25 & $7.6 \pm 2.3$ & $2.75 \pm 0.09$ & 17000 & $91 \pm 12$ \\
\hline 30 & Lochsa River & 46099'04" & $115^{\circ} 35^{\prime} 37^{\prime \prime}$ & 3055 & $465-2680$ & 21 & 72 & $26.3 \pm 2.8$ & $1.05 \pm 0.04$ & 6700 & $250 \pm 32$ \\
\hline 31 & Selway River & $46^{\circ} 05^{\prime} 11 "$ & $115^{\circ} 30^{\prime} 59^{\prime \prime}$ & 4945 & $490-2709$ & 21 & 70 & $24.5 \pm 3.2$ & $1.32 \pm 0.07$ & 8100 & $205 \pm 28$ \\
\hline 32 & Salmon River & $45^{\circ} 44^{\prime} 38^{\prime \prime}$ & 11619'39" & 35079 & $460-3859$ & 10 & 84 & $13.7 \pm 4.1$ & $1.47 \pm 0.08$ & 6300 & $261 \pm 36$ \\
\hline
\end{tabular}




\section{Notes for Table A}

*Identification numbers are coded to map in Figure A.

${ }^{\dagger}$ Sediment yields for catchments smaller than $20 \mathrm{~km}^{2}$ were measured by trapping sediment behind small dams; the trapped sediment was measured and removed once or twice per year (Clayton and Megahan, 1986). Measurements of suspended sediment passing over the dams were used to correct for trap efficiency.

Sediment yields for catchments larger than $20 \mathrm{~km}^{2}$ were calculated from daily measurements of streamflow, scaled by bias-corrected (Ferguson, 1987) sediment rating curves derived from measurements of suspended sediment concentrations and bedload fluxes over a wide range of flows. Periods of record for sediment concentrations (and thus for construction of rating curves) were 10, 14, 14, 10, 5, 4, 4, and 16 years for catchments no. 25 through 32 , respectively. Uncertainties (expressed as standard errors of means) were calculated from variability of annual fluxes. For catchments no. 32 and no. 29 , bedload was estimated as $5 \%$ and $10 \%$ of total sediment flux, respectively, and standard errors were estimated at 30 percent of the mean. N.D. = not determined.

$\$ 40$-gram samples of quartz were purified from sand-sized sediment by magnetic separation and by acid leaching (Kohl and Nishiizumi, 1992) (which also eliminates meteoric "garden variety" ${ }^{10} \mathrm{Be}$ ), spiked with $\sim 0.5 \mathrm{mg}{ }^{9} \mathrm{Be}$, and dissolved in $\mathrm{HF}$. Be was separated by ion chromatography and analyzed as ${ }^{10} \mathrm{Be} /{ }^{9} \mathrm{Be}$ by accelerator mass spectrometry at Lawrence Livermore National Laboratory.

${ }^{\#}$ Long-term sediment yields were calculated from equation 1. Area-averaged $P_{\mathrm{n}}$ and $P_{\mathrm{m}}$ values were calculated from sea-level high-latitude ${ }^{10}$ Be production rates $4.72 \pm 0.38$ atoms $\bullet \mathrm{g}^{-1} \cdot \mathrm{yr}^{-1}$ and $0.11 \pm 0.01$ atoms $\bullet \mathrm{g}^{-1} \cdot \mathrm{yr}^{-1}$ respectively (Riebe et al., 2000; Riebe et al., 2001), scaled for latitude and for the altitude distribution within

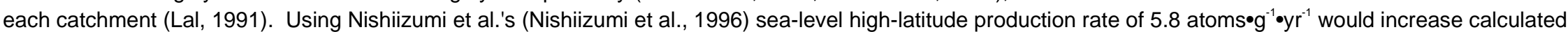
sediment yields by $\sim 20$ percent. Production rates were corrected for quartz enrichment by chemical weathering (Small et al., 1999), and for topographic shielding (Dunne et al., 1999). We corrected for shielding by snow cover using site-specific relationships between altitude and average snow water equivalent measured at nearby snow survey sites. Weathering fluxes were estimated at $W=10.7 \pm 0.4 \mathrm{~T} \mathrm{~km}^{-2} \bullet \mathrm{yr}^{-1}$, based on 11 -yr chemical mass balances at four Silver Creek catchments (Clayton and Megahan, 1986).

Clayton, J.L., and Megahan, W.F., 1986, Erosional and chemical denudation rates in the southwestern Idaho batholith: Earth Surface Processes and Landforms, v. 11, p. 389-400.

Dunne, J., Elmore, D., and Muzikar, P., 1999, Scaling factors for the rates of production of cosmogenic nuclides for geometric shielding and attenuation at depth on sloped surfaces: Geomorphology, v. 27, p. 3-11.

Ferguson, R.I., 1987, Accuracy and precision of methods for estimating river loads: Earth Surface Processes and Landforms, v. 12 , p. 95-104.

Kohl, C.P., and Nishiizumi, K., 1992, Chemical isolation of quartz for measurement of in-situ-produced cosmogenic nuclides: Geochimica et Cosmochimica Acta, v. 56, p. 3583-3587.

Lal, D., 1991, Cosmic ray labeling of erosion surfaces: in situ nuclide production rates and erosion models: Earth and Planetary Science Letters, v. 104, p. 424439.

Nishiizumi, K., Finkel, R.C., Klein, J., and Kohl, C.P., 1996, Cosmogenic production of 7Be and 10Be in water targets: Journal of Geophysical Research B, Solid Earth, v. 101, p. 22225-22232.

Riebe, C.S., Kirchner, J.W., Granger, D.E., and Finkel, R.C., 2000, Erosional equilibrium and disequilibrium in the Sierra Nevada, inferred from cosmogenic 26 Al and ${ }^{10}$ Be in alluvial sediment: Geology, v. 28, p. 803-806.

Riebe, C.S., Kirchner, J.W., Granger, D.E., and Finkel, R.C., 2001, Minimal climatic control on erosion rates in the Sierra Nevada, California: Geology, v. 29, p. 447-450.

Small, E.E., Anderson, R.S., and Hancock, G.S., 1999, Estimates of the rate of regolith production using Be-10 and Al-26 from an alpine hillslope: Geomorphology, v. 27 , p. $131-150$. 


\section{APPENDIX A}

To test whether shallow debris flows have a measurable effect on cosmogenic nuclide concentrations, we sampled and analyzed sand-sized material at two points along the debris flow scar at Circle End Creek (samples no. 22 and no. 24 in Table A). These samples yielded cosmogenic nuclide concentrations and long-term erosion rates that were indistinguishable from those of an undisturbed Circle End tributary (catchment no. 23) and adjacent undisturbed Tailholt Creek (catchments 18-21). This indicates that cosmogenic nuclide measurements of long-term erosion rates are not substantially affected by recent debris-flow activity, because the time required for a typical sediment grain to be exhumed from a hillslope and transported to a small channel or hollow is much longer than the timescale of its subsequent storage there. Thus the cosmogenic nuclide signature is primarily acquired during hillslope exhumation and transport, with channel storage having little effect on either nuclide production or decay (the latter requiring storage at depths $>1 \mathrm{~m}$ for timescales $>1 \mathrm{Myr}$, which is implausible at our sites). 